\title{
Sedimentuen toxikotasunaren azterketa integrala ekologikoki adierazgarriak diren espezieak erabiliz
}

\author{
(Integrative sediment toxicity assessment using ecologically relevant \\ species)
}

\author{
Nerea Garcia Velasco, Erik Urionabarrenetxea Gorroño, Manu Soto López, \\ Beñat Zaldibar Aranburu*
}

Zelulen Biologia Ingurumen Toxikologian (ZBIT) ikerketa taldea, Zoologia eta Animalia Zelulen Biologia Saila, Zientzia eta Teknologia Fakultatea eta Plentziako Itsas Estazioa (PiE), Euskal Herriko Unibertsitatea UPV/EHU (Euskal Herria)

\begin{abstract}
LABURPENA: Euskal kostaldean eta, nagusiki, estuarioetan, sedimentu ugari aurkitzen ditugu, egungo zein iraganeko giza jardueren eraginez substantzia toxiko ugari metatzen dituztenak. Horrek ingurumen-arazoak dakartza, eta sedimentu horiek modu egokian kudeatzera bultzatu behar gaitu. Horretarako, kutsatzaileok sedimentuetan duten portaera ulertu behar da, bai eta sedimentuen karakterizazio sakona egin ere. Gaur egunean indarrean dagoen legediak zenbait gidalerro eskaintzen dituen arren, hainbat lanek gidalerro horien mugak agerian utzi dituzte. Bereziki garrantzitsua da ohiko neurketa kimikoak sedimentuetan bizi diren organismoen ikerketekin uztartzea. Izan ere, haietan burutzen diren entseguek informazio oso baliagarria eskain dezakete sedimentuen toxikotasunaren eta, beraz, haien kudeaketa-beharraren inguruan. Entsegu horietarako erabiltzen diren bizidunek sedimentuan bizitzea eta han funtzio ekologiko garrantzitsua izatea komeni da. Horien artean $\mathrm{He}$ diste diversicolor poliketoa dugu, sedimentuen kutsaduraren ebaluaziorako eta bioentsegu zehatz eta fidagarriak burutzeko organismo aproposa dena. Horiez gain, in vitro teknika egokiak eta sentikorrak garatu dira espezie honetan, eta horrela esperimentazioan erabiltzen diren bizidunen kopurua mugatu egiten da. Beraz, gure sedimentuetan metatutako kutsatzaileen maila altuek izan ditzaketen arriskuen ebaluazio fidagarria lor daiteke, baldin eta analisi kimikoak eta ekologikoki adierazgarriak diren espezieetan gertatutako efektuak (analisi ekotoxikologikoak) integratzen badira.
\end{abstract}

HITZ GAKOAK: Itsasadarrak, kutsadura, toxikotasuna, adierazleak, bioentseguak.

\begin{abstract}
In the Basque coast and mainly in estuaries, sediment deposition and accumulation occurs. It is noteworthy that different human activities have influenced on sediments that have undergone important inputs of different toxic substances over the years and even today. Since polluted sediments could pose a risk for the environment, we should proceed properly for an accurate environmental management. For that, firstly it is necessary to study and understand the behavior of pollutants in sediments and then to carry out characterization of sediments. Although the legislation currently in force provides certain guidelines, several works have revealed the limitations of these policies. Therefore, in addition to conventional chemical measurements, organisms living in estuarine sediments and tests performed in them can provide very useful information on sediment toxicity (and thus future use and management). Mainly, if these sentinel organisms are ecologically relevant species that inhabit those niches. Among organisms living in sediment, the polychaete Hediste diversicolor has been used for sediment toxicity assessment using bioassays. Moreover, in vitro techniques have been described in this species as very useful tools, limiting the number of organisms used in experiments and showing them as sensitive tools. Therefore, a reliable assessment of the hazards resulting from high levels of pollutants in sediments can be achieved, after integrating chemical analysis and effects measured in ecologically relevant species (ecotoxicological analysis).
\end{abstract}

KEYWORDS: Estuaries, pollution, toxicity, indicators, bioassays.

* Harremanetan jartzeko / Corresponding author: Beñat Zaldibar Aranburu, CBET Research Group. Dept. Zoology and Animal Cell Biology, Faculty of Science and Technology, UPV/EHU, Barrio Sarriena s/n, E-48940 Leioa. Bizkaia. Euskal Herria. benat.zaldibar@ehu.eus - https://orcid.org/0000-0002-5528-451X.

Nola aipatu / How to cite: Garcia Velasco, Nerea; Urionabarrenetxea Gorroño, Erik; Soto López, Manu; Zaldibar Aranburu, Beñat (2020). "Sedimentuen toxikotasunaren azterketa integrala ekologikoki adierazgarriak diren espezieak erabiliz»; Ekaia, ale berezia 2020, 221-231. (https://doi.org/10.1387/ekaia.21058).

Jasoa: 31 uztaila, 2019; Onartua: 11 azaroa, 2019

ISSN 0214-9001 - elSSN 2444-3255 / (C) 2020 UPV/EHU

(c) (i) () Obra hau Creative Commons Atribución 4.0 Internacional-en

lizentziapean dago 
Nerea Garcia Velasco, Erik Urionabarrenetxea Gorroño, Manu Soto López, Beñat Zaldibar Aranburu

\section{SARRERA}

Higadurak lehorraldetik askatzen dituen partikulak metatzean sortzen diren materialak dira sedimentuak. Partikula horiek, normalean, uraren bitartez (baita haize edo glaziarren bidez ere) garraiatzen dira, eta gehienetan ibai, laku eta itsasadarretan metatzen dira. Gure kostaldean ere, sedimentu asko metatzen da ibaiek garraiatutako materialaren ondorioz. Gure itsasadar eta kaietako sedimentuek urteetan zehar giza jarduerekin erlazionatutako substantzia asko jaso dituzte, eta industria askotarikoak, hiri-isurketak (araztegiak, adibidez) edo turismoa (kostaldeko zonaldeetan gertatzen den bat-bateko populazio gorakadekin erlazionatuta) dira, besteak beste, substantzia horien iturri nagusiak. Uretara heldu diren konposatu asko urzutabean disolbatu eta itsasoan zehar barreiatzen dira. Beste asko, aldiz, ez dira uretan disolbatzen eta sedimentuetara atxiki edota haietan metatzen dira [1]. Substantzia horietako askok sedimentuen kutsadura eragin dezakete, eta han bizi diren organismoen osasunaren eta ekosistemaren ongizatea kaltetu. Gainera, sedimentuek urteetan zehar kutsatzaileak lotuta manten ditzakete, eta horrela, sedimentua bera kutsatze-iturri bilaka daiteke eta giza osasuna ere negatiboki kaltetu [2].

Hortaz, kutsaturiko sedimentuek sor ditzaketen arrisku toxikologikoen ikertzeak berebiziko garrantzia du. Haien toxikotasun maila ezagutzeko beste arrazoi bat dragaturiko sedimentuen erabilera da; hala nola, industrian, portuen garapenean eta lurzoruaren betetze-lanetan. Sedimentuen kutsadura-maila ezagutzeko asmoz, sedimentuan dauden konposatuen (metalak, metaloideak, konposatu organikoak) kontzentrazio totalak neurtzen dira. Konposatu horien artean, beren iraunkortasun- eta biometaketa-ahalmenagatik Europar Batasuneko Uren Arteztarauan (2000/60/EC, WFD edo Water Framework Directive) kutsatzaile nagusitzat hartzen diren elementuak daude (kadmioa, merkurioa, beruna eta nikela). Batetik, analisi kimiko horien bitartez, kutsatzaileek estuariotan zehar duten hedapen espazial eta tenporalaren informazioa jaso daiteke [3]. Bestetik, analisi kimiko horietako datuak kalitate estandarrekin konpara daitezke sedimentuen kalitatea/egoera ezagutzeko. Hala ere, sedimentuen osasun-maila ezagutzeko, kutsaduraren eragin biologikoa neurtu beharra dago, ahal izanez gero, sedimentuan bertan bizi diren espezieak erabiliz. Izan ere, ekologikoki adierzagarriak diren espezieetan burutzen diren entseguek informazio oso baliagarria eskain dezakete sedimentuen toxikotasunaren eta, beraz, haien kudeaketa-beharraren inguruan.

\section{KUTSATZAILEEK SEDIMENTUETAN ETA DRAGATZEETAN ERAKUTSITAKO PORTAERAK}

Sedimentuan dauden kutsatzaile guztiek ez dute zertan hango bizidunentzat eskuragarri egon, eta, beraz, ez dute zertan haiengan efektu 
nabarmenik eragin. Soilik organismoetan barneratzen diren edo haiekin interakzioak dituzten kutsatzaileak dira toxikoak (edo toxiko izateko arriskua dago). Kutsatzaileek sedimentuetan duten toxikotasun edo/eta eskuragarritasunean hainbat faktorek eragiten dute: besteak beste, sedimentuaren ehundurak, materia organikoaren edukiak, $\mathrm{pH}-\mathrm{ak}$, erredox potentzialak edo gazitasunak [4]. Beraz, sedimentuen osasuna edo toxikotasuna aztertzeko orduan, faktore horiek paper garrantzitsua jokatzen dute.

Sedimentuen ehundurak, adibidez, kutsatzaileen adsortzioan zuzenean eragiten du. Metalek, adibidez, sedimentuetako partikulen azaleran itsasteko joera dute. Partikula horiek zenbat eta txikiagoak izan, orduan eta azalera/bolumen erlazio handiagoa dute. Horregatik, bikor oso finez osatutako sedimentuen baitan gainazal handiagoa izaten da orotara, eta metal gehiago atxikitzeko joera dago. Bestalde, materia organikoak (bakterioek eta meiofaunak ekoitzita nagusiki) ere pikor txikiei itsasteko joera $\mathrm{du}$, eta, beraz, kutsatzaile organiko asko sedimentuen materia organikoari lotzen zaizkio [5], bereziki pikor finez osatutako sedimentuetan. Bestetik, sedimentuak osatzen dituzten mineralak (zehazki sufretan aberatsak direnak) metal astunekin lotzen dira, eta hauen bahiketa eta prezipitazioa (eta, beraz, immobilizazioa) bultzatzen duten metal sulfuro disolbagaitzak eratzen dira. Horretaz gain, $\mathrm{pH}$ altuek eta erredox potentzial baxuek metalen metaketa eta immobilizazioa eragin dezakete. Beste alde batetik, gazitasun altuak, presio osmotikoa dela eta, bakterio sulfato erreduzitzaileen hazkuntza inhibitzen du, eta sulfuroen sorrera mugatu eta metalaren eskuragarritasuna emendatu. Gainera, gazitasunaren emendioak hainbat katioiren $(\mathrm{Na}, \mathrm{K}$ edo $\mathrm{Mg}$ ) ugaritzea dakar, eta metalen mobilizazioa erraztea [6].

Gure kostalde eta itsasadarrak maiz dragatzen dira, metatzen diren sedimentuek itsasontzien ibilbidea eragotz dezaketelako edo uholde-arriskua emendatzen dutelako. Horrek hiru galdera garrantzitsu sortzen dizkigu. Nola eragiten du dragatzeak sedimentuek urteetan zehar metatu dituzten kutsatzaileetan? Zer egin behar da erauzitako sedimentuekin? Nolako toxikotasuna dute sedimentuek eta nola neurtzen da? Ondorengo lerroetan, galdera horien inguruko hausnarketa egiten saiatuko gara.

Dragatze-lanak burutzen direnean, aldaketa fisiko, kimiko eta biologiko garrantzitsuak gertatzen dira sedimentuetan. Alde batetik, hango partikulak mobilizatzen dira eta uretan esekidurara igaro. Haiek oso finak badira, luzaroan geratzen dira esekiduran, uren uhertasuna handituz eta hondora heltzen den argiaren intentsitatea murriztuz. Hori dela eta, itsasadarraren ekoizpen primarioa txikitu egiten da, eta, horrekin lotuta, ekosisteman asaldurak agertzen dira. Besteak beste, esekiduran dauden gehiegizko materialek ornogabeen populazioen kopuru eta dibertsitatea murriztu, arrainetan ugalketa mugatu eta haien ugaritasuna txikitu dezakete [7]. 
Beste alde batetik, sedimentua mugitzean ur-zutabearen oxigenoarekin kontaktuan jartzen da. Sedimentu anoxikoak oxigenoarekin kontaktuan sartzean, erredox potentziala igotzen da, eta, horrekin batera, hainbat bakterioren (tiobakterioak, besteak beste) jarduera; ondorioz, sulfuroak sulfatoetara oxidatzen dira, eta $\mathrm{pH}-\mathrm{a}$ murriztu. Hori dela eta, sulfuroari loturik dauden metalak askatu egiten dira eta organismoentzat eskuragarri gelditzen dira. Batzuk, hala nola merkurioa, kadmioa eta beruna, azkar askatzen dira; beste batzuk, aldiz, zinka kasurako, motelago [8] (1. irudia).

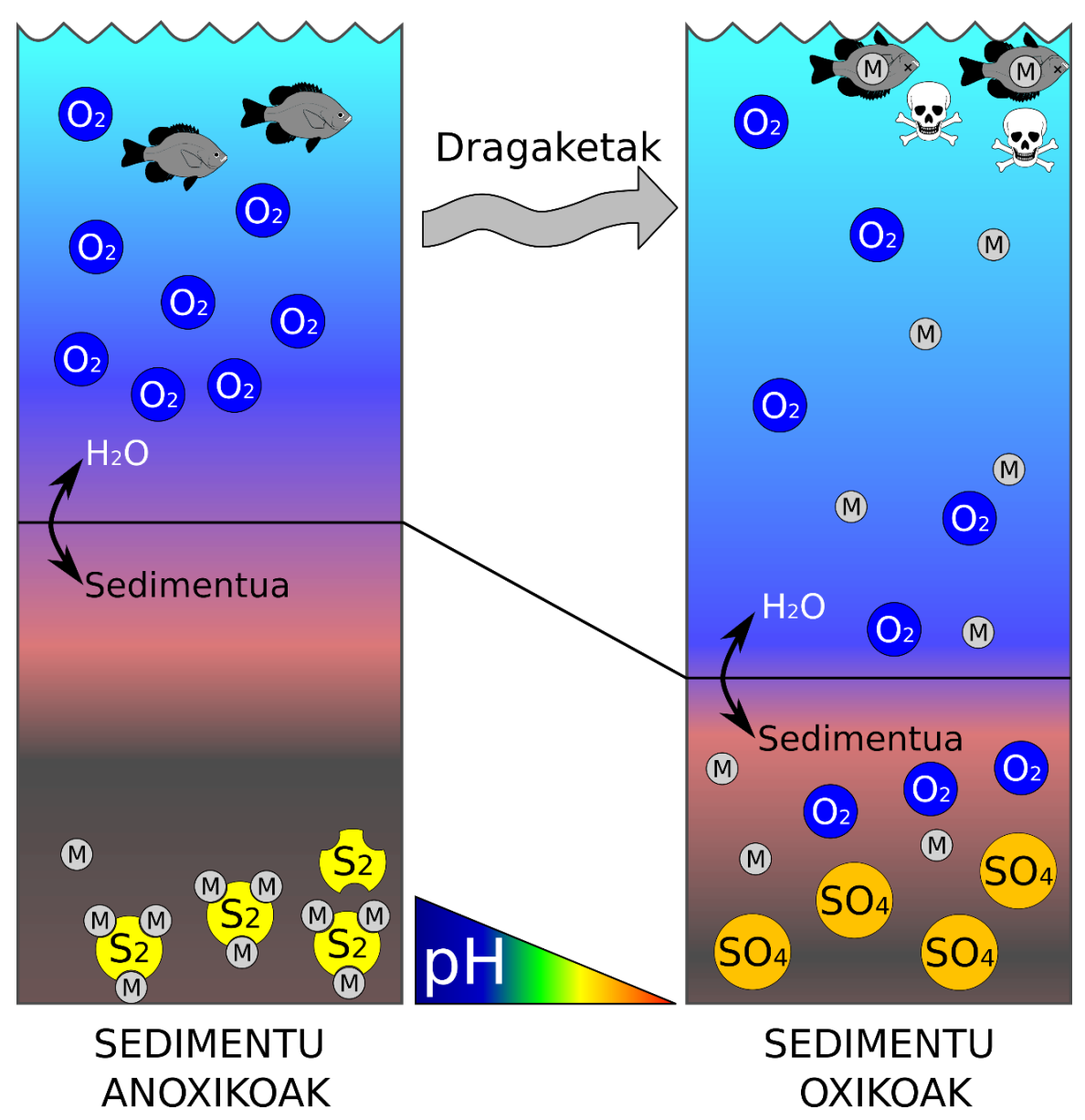

1. irudia. Dragaketaren ondorioz gertatutako sedimentuen oxigenazioa, non erredox potentzialaren igoera dela-eta sulfuroaren oxidazioa sulfatora gertatzen baita, eta $\mathrm{pH}$-aren jaitsiera gertatzen baita. Sulfatoen metalekiko afinitatea txikiagoa izanik, metalak (M) askatu egiten dira, eta organismoentzat eskuragarriago bihurtu. 
Kutsatzaile organikoen kasuan ere, sedimentuen mobilizazioak haien askapena eragin dezake, baina kasu horretan bakterioen bidezko degradazioa eta oxidazioa ahalbidetzen da. Sedimentu sakon anoxikoak sedimentu azal oxigenatuekin kontaktuan jartzean, adibidez, metilmerkurioa askatzen da, materia organikoz eta metalez osatutako konposatu toxikoa. PCB-ak (Bifenil poliklorinatuak; ingelesez, Polychlorinated Biphenils) bezalako kutsatzaileak baldintza anoxikoetan degradatuz doaz erreakzio deklorinatzaile erreduzitzaileen bitartez. Horrela, prozesuan zehar toxikoagoak edo eskuragarriagoak diren bitartekariak sortzen dira [5].

\section{ZER EGIN JASOTAKO SEDIMENTUEKIN?}

Dragatze-lanen eraginez, urtero milioika metro kubo sedimentu eskuratzen dira. Espainian, bataz beste 8.7 milioi metro kubo [9] eta Europako zenbait herrialdetan (Herbehereak, Alemania, Frantzia eta Erresuma Batua), 30 eta 50 milioira iristen da kantitate hori [10]. Ateratako materialaren zati handi bat berriz itsasora isurtzen da itsasadarretako korronteak mantentzeari begira. Hala ere, sedimentuek beste erabilera asko izan ditzakete; hala nola, ingeniaritzan, nekazaritzan edota ingurumena hobetzen. Adibidez, eraikuntzarako betegarri gisa erabil daitezke dragaturiko materialak (arroka, legar eta hareak), baina baita lurren hobekuntza eta berreskurapenerako ere, hondartzak zabaltzeko edota uholdeetatik babestuko gaituzten lezoiak eraikitzeko. Material hauek erabili baino lehen, ezinbestekoa da lehortzea; eta kasu batzuetan, tratatu egin behar dira, batez ere buztinak eta lohiak: izan ere, kutsadura-maila esanguratsuak izan ditzakete.

Dragatutako material gehienek kutsadura-maila baxua izaten dute, eta, beraz, haien isurketaren inpaktu nagusia fisikoa izaten da: adibidez, itsas hondoko espezieak zapaltzen dira. Hala ere, aipatu dugun moduan, sedimentu batzuk, bereziki lohitsu eta buztintsuek, urtean zehar kutsatzaile asko metatu ahal izan dituzte. Horrelako kasuetan, sedimentu horiek erabili aurretik, tratatu egin behar dira. Hori dela eta, sedimentuen dragatzea edota maneiurako kudeaketa-programa bereziak eta legedi espezifikoak garatu dira [9].

\subsection{Zer dio araudiak?}

Espainiar Estatuan indarrean dagoen araudiaren arabera [9], badira inongo karakterizaziorik behar ez duten sedimentuak, hala nola, jarduera kutsatzailerik izan ez duten $10.000 \mathrm{~m}^{3}$-rainoko dragatzeak, material geologiko kontsolidatuz (sedimentatutako edo zementatutako arrokaz osoturiko materialak), edota $2 \mathrm{~mm}$ baino pikor handiagoz osatutako sedimentuak, hauek kutsatzaile gutxi atxikitzen baitituzte. Gainerako guztiek karakterizazio kimiko eta biologikoa behar dute, bi kategoriatan sailkatuz: sedimentu 
Nerea Garcia Velasco, Erik Urionabarrenetxea Gorroño, Manu Soto López, Beñat Zaldibar Aranburu

arriskutsuak edo ez-arriskutsuak. Horretarako, sedimentuetan dauden kutsatzaileen kontzentrazioak legediak ezartzen dituen atalase-balioekin (1. taula) alderatzen dira.

1. taula. Sedimentua arriskutsu kontsideratzeko atalase-balioak [9]tik hartuak. ( $\Sigma 7$ PCB: IUPAC 28, 52, 101, 118, 138, 153 eta 180 kidekoen batura litzateke. $\Sigma 9$ PAH (Hidrokarburo Polizikliko Aromatikoak; Ingelesez Polycyclic Aromatic Hydrocarbons): Antrazenoa, Benzo(a)antrazenoa, Benzo(ghi)perilenoa, Benzo(a)pirenoa, Krisenoa, Fluorantenoa, Indeno(1,2,3-cd)pirenoa, Pirenoa eta Fenantrenoa kontzentrazioen batura litzateke. TBT siglek tributileztainuari (Ingelesez, Trybutyltin) eta bere degradazio produktuei egiten diete erreferentzia).

\begin{tabular}{cc}
\hline Kutsatzailea & Kontzentrazioa $(\mathrm{mg} / \mathrm{kg})$ \\
\hline $\mathrm{Hg}$ & 17 \\
\hline $\mathrm{Cd}$ & 75 \\
\hline $\mathrm{Pb}$ & 1.000 \\
\hline $\mathrm{Cu}$ & 2.500 \\
\hline $\mathrm{Zn}$ & 2.500 \\
\hline $\mathrm{Cr}$ & 1.000 \\
\hline $\mathrm{Ni}$ & 1.000 \\
\hline $\mathrm{As}$ & 1.000 \\
\hline$\Sigma 7$ PCB & 4 \\
\hline$\Sigma 9$ PAH & 110 \\
\hline TBT $(\mathrm{Sn})$ & 1.2 \\
\hline Hidrokarburoak C10-C40 & 2.500 \\
\hline
\end{tabular}

Sedimentu arriskutsuak estali, edo urpeko gune mugatu batera eraman behar dira, bidean zein metatzerakoan materialaren dispertsioa mugatzeko. Aldiz, sedimentu ez-arriskutsuak beste hiru azpi-kategoriatan (A, B edo C) sailkatzen dira beren kontzentrazio kimiko eta parametro ekotoxikologikoen arabera. A kategoriak sedimentu garbiena biltzen du, eta $\mathrm{C}$ kategoriak arriskutsu izan gabe kutsatuen dagoena. Sedimentu horiek itsasoan isuri nahi baldin badira, sailkapen horren arabera egin behar da: A kategorikoak arazo barik isuri ahal dira esklusio-aldeetan izan ezik; B kategorikoak berdin, baldin eta ez bada ez esklusio- eta ez murrizketa-aldeetan; eta $\mathrm{C}$ kategorikoak, aldiz, era konfinatu batean bakarrik isuri ahal dira itsasoan, baldin eta tratatzen ez badira. 
Sedimentuen toxikotasuna analisi kimiko hutsez aztertzeak baditu bere mugak; batetik, zenbait konposatuentzat detekzio-mugak altu samarrak direlako, eta bestetik, neurtuko diren konposatuen arabera erabiltzen diren erauzketa-prozesuek analisietan eragina izan dezaketelako. Bestetik, kutsatzaileen bioeskuragarritasuna eta kutsatzaile-nahasketa konplexuek duten arriskua ezin dira analisi kimiko bitartez neurtu [10]. Hori dela eta, sedimentuetan dauden kutsatzaileen arrisku potentziala ezagutzeko, analisi kimikoak eta eragin biologikoak batzen dituen analisi integratua erabiltzen da. Espainiako gidalerroetan sedimentuetako kutsatzaileek bizidunetan izan ditzaketen efektuak zehazteko bioentseguak aipatzen diren arren, haien emaitzak oraindik nekez hartzen dira kontuan kudeaketa-planetan.

\section{SEDIMENTUEN TOXIKOTASUNA NEURTZEKO TRESNA BIOLOGIKOAK}

Sedimentu kutsatuen eragin biologikoa ikertzeko, hainbat organismo erabili izan dira: bakterioak, krustazeoak, moluskuak, itsas trikuak eta poliketoak, besteak beste $[11,12]$. Espezie horiekin bioentseguak egin izan dira nagusiki, konposatu kimikoek edo haien nahasketek sor ditzaketen efektu biologikoak neurtzeko eta kuantifikatzeko testak, alegia [10]. Sedimentuen toxikotasuna aztertzeko erabiltzen diren bioentsegu estandarren artean, itsas trikuen enbrioiekin burutzen diren testak daude [13]. Entsegu horiek errazak, merkeak eta sentikorrak dira, baina enbrioiak ez daude eskuragarri urte osoan zehar, animalia horiek ugaltze-garai mugatua baitute, eta aipatutako biontseguak mugatzen dituzte. Beste aukera bat dira Corophium volutator anfipodoa eta Arenicola marina poliketoa erabiltzen dituzten test estandarrak $[14,15]$. Espezie horiek urte osoan ugariak dira, banaketa zabala dute, partikulen tamaina eta gazitasun-tarte zabala onartzen dute, eta eragin garrantzitsua dute bentoseko komunitatearen antolaketan [16]. Hala ere, espezie horiek hondartza eta zonalde hareatsuetan bizi dira, eta, beraz, ez dira horren aproposak lohitsuak diren sedimentuetarako. Hori dela eta, sedimentuen kutsaduraren ondorioak zehatz neurtzeko, komenigarriagoa litzateke gure sedimentuetan bizi diren espezieak hautatzea.

Hediste diversicolor sedimentuetan ugaria den eta banaketa geografiko zabala duen (euskal kostaldea barne) poliketoa da. Espezie honek estuarioetako kate trofikoetan garrantzi handia dauka, krustazeo, arrain eta hegaztien dietetan sartzen baita; hortaz, estuarioetako espezie gakotzat hartu izan da [17]. Bestalde, espezie honek mantenu erraza du laborategian, dentsitate altuetan bizirik manten daitekeelako ur gazitako sedimentu lohitsu$\tan$ [23]. Aurreko abantailak kontuan izanda eta komunitate bentonikoaren adierazle izanik, hainbat egilek $H$. diversicolor organismo behaletzat hartu izan dute kutsaduraren ebaluaziorako, biomonitorizazio programetan, edota bioentsegu zehatz eta fidagarriak burutzeko. Beraz, H. diversicolor polike- 
Nerea Garcia Velasco, Erik Urionabarrenetxea Gorroño, Manu Soto López, Beñat Zaldibar Aranburu

toa sedimentuen osasuna ebaluatzeko erantzun fidagarriak eskaintzen dituen espeziea da. Espezie honekin egindako ikerlanen emaitzek bere sentikortasuna erakutsi dute, batez ere metalekiko [18].

\subsection{Bioentseguak, biomarkatzaileak eta in vitro test-ak Hediste diversicolor poliketoan}

$H$. diversicolor-ekin bioentseguak egiten dituzten ikerlan gehienetan, poliketoak metal-kontzentrazio jakinen pean izan dira $(\mathrm{Cu}, \mathrm{Zn}, \mathrm{Cd}$, nanopartikula metalikoak eta abar), ondoren haien hilkortasuna eta kutsatzaileen metaketa aztertzeko $[19,20]$. Oinarrizko neurketa horietaz gain, poliketoen tunelak egiteko gaitasuna eta birsorkuntza-ahalmena ere neurtu izan dira [21]. Dena den, kudeaketa burutzeko beharrezkoak diren hilkortasun- edo efektu-datuak eskuratzeaz aparte (adibidez, $\mathrm{LC}_{50}$, populazioaren $\% 50$ hiltzeko dosia), ezinbestekoa da ondorio subletalak aztertzea ingurumenaren osasun-egoera definitu ahal izateko. Horretarako, antolakuntza-maila desberdinetan gerta daitezkeen aldaketak edo biomarkatzaileak erabili behar dira. Kutsatzaile edota bestelako ingurumen-faktore estresatzaile batek eragindako aldaketa biokimiko, zelular, edo fisiologikoei biomarkatzaile deritze. Tresna hauek ur-zutabean bizi diren organismo iragazleetan aplikatu izan dira nagusiki (muskuiluak, txirlak). Hala ere, badira $H$. diversicolor poliketoan konplexutasun-maila ezberdinetan biomarkatzaileak neurtzen dituzten lanak: geneen adierazpena, genotoxizitatea, entzima antioxidanteen aldaketak eta parametro zelularrak, besteak beste $[19,22]$.

Maila zelularrean, anelidoen zelula immuneak (zelomozitoak) landu izan dira, kutsatzaile ugariren aurrean duten sentikortasunagatik [23]. Zelomozitoak organismoaren ongizatea mantentzeko funtzioa duten zelulak direnez, kutsatzaile-kontzentrazio baxuen aurrean ere erantzunkorrak dira [24]. Gainera, zelulen erantzunak neurtuz konplexutasun-maila altuagoetan (ehun, organismo) pairatutako kalteak aurreikus daitezkeela ondorioztatu da [25]. Beraz, sedimentuen kutsadura aztertzeko, aproposa litzateke $H$. diversicolor poliketoaren zelomozitoen hazkuntza primarioak garatzea. Zelomozitoak zeloman aske egoten dira, eta poliketoetatik erraz erauz daitezkeenez, hautagai onak dira in vitro entseguak burutzeko. Horretarako, zelomozitoak sedimentuetatik eratorritako elutriatuen pean jartzen dira ondoren zelulen hilkortasuna mikroplaketan espektrofotometriaz, fluorimetriaz edo fluxu zitometroaz neurtzeko.

Orain arte $H$. diversicolor poliketoarekin egindako lanek artifizialki kutsaturiko sedimentuak erabili dituzte batez ere, eta urria izan da zelaian hartutako sedimentuen erabilera. Aldiz, aipatutako bioentsegu, biomarkatzaile eta in vitro testen konbinazio horiek gure itsasadar eta kostaldeko sedimentu errealetan aplikatuko balira, haien osasunaren ebaluazio zehatza es- 
kuratuko genuke. Konplexutasun biologiko-maila desberdinetan neurturiko efektuen emaitzak indize integratzaileetan (Erantzun Biologikoen Indizea; Ingelesez Biological Response Index delakoan, adibidez) [26] sar daitezke kutsaduraren arriskua estimatzeko. Indize horien emaitza integratuak kutsaturiko sedimentuen kudeaketa-gidalerroen jarraipenerako eta araudia betetzeko lagungarri izateaz gain, sedimentuen osasunaren berri jakiteko tresna baliagarriak dira.

Sedimentuetan metatutako kutsatzaile-maila altuek eragin ditzaketen arriskuen ebaluazio fidagarri bat lortzeko, ezinbestekoa da kutsatzaileen sedimentu-ura interfasearen fluxu dinamikak ezagutzea eta ekologikoki garrantzitsuak diren espezieetan toxikotasun-proba zehatz eta fidagarriak aplikatzea. Horrela, biomarkatzaileak konplexutasun biologikoaren maila desberdinetan neurtuz, emaitza osoagoa lor daiteke.

\section{ESKER ONAK}

MINECO. Proyectos I+D+I, del Programa Estatal de Investigación, Desarrollo e Innovación Orientada a los Retos de la Sociedad. Convocatoria 2017. Erreferentzia: CTM2017-87766-R (Nuevas perspectivas sobre las amenazas ecotoxicológicas latentes que plantean los sedimentos estuarinos cronicamente contaminados. Seadimentox).

\section{BIBLIOGRAFIA}

[1] BARCELÓ, D., PETROVIC, M. 2007. Sustainable Management of Sediment Resources Sediment Quality and Impact Assessment of Pollutants. Elsevier. Amsterdam.

[2] ChAPMAN, P.M., HO, K.T., MUNNS JR., W.R., SOlOMON, K., WEINSTEIN, M.P. 2002. Issues in sediment toxicity and ecological risk assessment. Marine Pollution Bulletin 44, 271-278.

[3] PARSONS, J., BELZUNCE SEGARRA, M.J., CORNELISSEN, G., GUSTAFSSON, O., GROTENHUIS, T., HARMS, H., JANSSEN, C.R., KUKKONEN, J., VAN NOORT, P., ORTEGA CALVO, J.J., SOLAUN ETXEBERRIA, O. 2007. Characterisation of contaminants in sediments effects of bioavailability on impact. Sustainable Management of Sediment Resources: Sediment Quality and Impact Assessment of Pollutants, Elsevier. Bartzelona.

[4] ZHANG, C., YU, Z-G., ZENG, G-M., JIANG, M., YANG, Z-Z., CUI, F., ZHU, M-Y., SHEN, L-Q., HU, L. 2014. Effects of sediment geochemical properties on heavy metal bioavailability. Environment International 73, 270-281. 
Nerea Garcia Velasco, Erik Urionabarrenetxea Gorroño, Manu Soto López, Beñat Zaldibar Aranburu

[5] EGGLETON, J., THOMAS, K.V. 2004. A review of factors affecting the release and bioavailability of contaminants during sediment disturbance events. Environment International, 30, 973-980.

[6] DU LAING, G., RINKLEBE, J., VANDECASTEELE, B., MEERS, E., TACK, F.M.G. 2009. Trace metal behaviour in estuarine and riverine floodplain soils and sediments: A review. Science of the Total Environment, 407, 3972-3985.

[7] WOOD, P.J., ARMITAGE, P.D. 1997. Biological Effects of Fine Sediment in the Lotic Environment. Environmental Management 21, 203-217.

[8] CAILlE, N., TIFFREAU, C., LEYVAL, C., MOREL, J.L. 2003. Solubility of metals in an anoxic sediment during prolonged aeration. Science of the Total Environment, 301, 239-250.

[9] COMISIÓN INTERMINISTERIAL DE ESTRATEGIAS MARINAS (CIEM) 2015. Directrices para la caracterización del material dragado y su reubicación en aguas del dominio público marítimo-terrestre. 173 orr.

[10] HANSEN, P.D., BLASCO, J., DELVALLS, T.A., POULSEN, V., VAN DEN HEUVEL-GREVE M. 2007. Biological analysis (Bioassays, Biomarkers, Biosensors) Sustainable Management of Sediment Resources: Sediment Quality and Impact Assessment of Pollutants, Elsevier Science, Bartzelona.

[11] CASADO-MARTÍNEZ, M.C.; BEIRAS, R.; BELZUNCE, M.J.; GONZÁLEZ-CASTROMIL, M.A., MARÍN-GUIRAO, L.; POSTMA, J.F.; RIBA, I., DELVALLS, T.A. 2006. Inter-laboratory assessment of marine bioassays to evaluate environmental quality of coastal sediments in Spain: III. The whole sediment toxicity test using crustacean amphipods. Ciencias Marinas, 32(1B), 149-157.

[12] BOEHLER, S.; STRECKER, R.; HEINRICH, P.; PROCHAZKA, E.; NORTHCOTT, G.L.; ATARIA, J.M.; LEUSCH, F.D.L.; BRAUNBECK, T.; TREMBLAY, L.A. 2017. Assessment of urban stream sediment pollutants entering estuaries using chemical analysis and multiple bioassays to characterise biological activities. Science of the Total Environment, 593-594, 498507.

[13] BEIRAS R, DURÁN I, BELLAS J, SÁNCHEZ-MARÍN P. 2012. ICES Techniques Mar Environmental Sciences No. 51. 13orr.

[14] ENVIRONMENTAL PROTECTION AGENCY (EPA). 1994. Methods for assessing the toxicity of sediment-associated contaminants with estuarine and marine amphipods. Rhose Island. USA. 156 orr.

[15] THAIN, J., BIFIELD, S. 2001. «Biological effects of contaminants: Sediment bioassay using the polychaete Arenicola marina». ICES Techniques in Marine Environmental Sciences, No 29. 23 orr.

[16] LIMIA, J.M., RAFFAELLI, D. 1997. The effects of burrowing by the amphipod Corophium volutator on the ecology of intertidal sediments. Journal of Marine Biology Association of the United Kingdom 77, 409-423.

[17] DUROUA, C., MOUNEYRAC, C., AMIARD-TRIQUET, C. 2008. Environmental quality assessment in estuarine ecosystems: Use of biometric 
measurements and fecundity of the ragworm Nereis diversicolor (Polychaeta, Nereididae). Water Research, 42, 2157-2165.

[18] GARCIA-VELASCO, N., URIONABARRENETXEA, E., DE DIEGO, A., IZAGIRRE, U., GREDILlA, A., CARRERO, J.A., LIÑERO, O., MARIGÓMEZ, I., SOTO, M. Developing novel sediment toxicity bioassays with Hediste diversicolor polychaete coelomocytes. Posterra SETAC Europe 29th Annual Meeting Kongresuan. Helsinki, Finland 26-30 May 2019.

[19] FREITAS, R., PIRES, A., MOREIRA,A., WRONA, F.J., FIGUEIRA, E., SOARES, A. M.V.M. 2016. Physiological and biochemical impacts induced by mercury pollution and seawater acidification in Hediste diversicolor. Marine Environmental Research, 117, 75-84.

[20] MOREIRA, S.M., LIMA, I., RIBEIRO, R., GUILHERMINO, L. 2006. Effects of estuarine sediment contamination on feeding and on key physiological functions of the polychaete Hediste diversicolor: Laboratory and in situ assays. Aquatic Toxicology 78, 186-201.

[21] DE MARCHI, L., NETO, V, PRETTI, C, FIGUEIRA, E., CHIELLINI, F., SOARES, A.M.V.M., FREITAS, R. 2017. Physiological and biochemical responses of two keystone polychaete species: Diopatra neapolitana and $\mathrm{He}$ diste diversicolor to Multi-walled carbon nanotubes .Environmental Research 154, 126-138.

[22] BUFFET, P.E., MARION, R., CAUPOS, F., VERGNOUX, A., PERREINETTAJANI, H...MOUNEYRAC, C. 2013. A Mesocosm Study of Fate and Effects of CuO Nanoparticles on Endobenthic Species (Scrobicularia plana, Hediste diversicolor). Environmental Science and Technology. 47, 16201628.

[23] IRIZAR, A., GARCIA-VELASCO, N., GONI DE CERIO, F., ETXEBARRIA, J., MARIGÓMEZ, I., SOTO, M. 2015. Establishment of toxicity thresholds in subpopulations of coelomocytes (amoebocytes vs. eleocytes) of Eisenia fetida exposed in vitro to a variety of metals: implications for biomarker measurements. Ecotoxicology. 24,1004-1013.

[24] HAYASHi, Y., ENGELMANN, P., FOLDBERG, R., SZABO, M., POLLAK, E., HECKMANN, L-H. 2012. Earthworms and humans in vitro: Characterizing evolutionarily conserved stress and immune responses to silver nanoparticles. Environmental Science and Technology 46, 4166-4173.

[25] CURIESES, S.P, GARCIA-VELASCO, N., URIONABARRENETXEA, E., SÁENZ, M.E, BILBAO, E., DI MARZIO, W.D., SOTO, M. 2017. Responses to silver nanoparticles and silver nitrate in a battery of biomarkers measured in coelomocytes and in target tissues of Eisenia fetida earthworms. Ecotoxicology and Environmental Safety 141, 57-63.

[26] MARIGÓMEZ, I., GARMENDIA, L., SOTO, M., ORBEA, A., IZAGIRRE, U., CAJARAVILLE, M.P. Marine ecosystem health status assessment through integrative biomarker indices: a comparative study after the Prestige oil spill «Mussel Watch». Ecotoxicology 22, 486-505. 